\title{
Implementasi DC-DC Boost Converter Menggunakan Arduino Berbasis Simulink Matlab
}

\author{
Randy Setiawan ${ }^{1}$, Muldi Yuhendri ${ }^{2}$ \\ 1,2Jurusan Teknik Elektro, Faklutas Teknik Universitas Negeri Padang \\ Jl. Prof. Dr. Hamka, Air Tawar Padang, 25132, Indonesia \\ randysetiawan170808@gmail.com ${ }^{1}$,muldiy@ft.unp.ac.id ${ }^{2}$
}

\begin{abstract}
Direct current (dc) voltage sources are one of the voltage sources most widely used for various purposes. Dc voltage can be obtained from a dc generator or by converting an ac voltage into a dc voltage using a power converter. There are several dc voltage levels that are commonly used by electrical and electronic equipment. To get a dc voltage that can be used for various equipment, then a dc voltage source must be varied according to the required. One way to get a variable dc voltage is to use a dc-dc converter. This research proposes a dc-dc boost converter that can increase the dc voltage with varying outputs. The boost converter is proposed using Arduino Uno as a controller with an input voltage of 12 volts. The converter output voltage regulation is implemented through Arduino programming using Matlab simulink. The experimental results show that the boost converter designed in this study has worked well as intended. This can be seen from the boost converter output voltage which is in accordance with the reference voltage entered in the Matlab simulink program.
\end{abstract}

Keywords - Boost converter, arduino uno, matlab simulink, dc voltage.

\begin{abstract}
Abstrak - Sumber tegangan searah atau direct current (dc) adalah salah satu sumber tegangan listrik yang banyak digunakan untuk berbagai keperluan. Tegangan searah dapat diperoleh dari pembangkit tegangan searah atau dengan mengkonversikan tegangan bolak balik menjadi tegangan searah menggunakan konverter daya. Ada beberapa level tegangan searah yang umum digunakan oleh peralatan listrik maupun elektronik. Untuk mendapatkan tegangan searah yang bisa dipakai untuk berbagai peralatan, maka dibutuhkan sumber tegangan searah yang dapat divariasikan sesuai dengan kebutuhan. Salah satu cara untuk mendapatkan tegangan searah yang bervariasi adalah dengan menggunakan konverter dc-dc. Penelitian ini mengusulkan konverter dc-dc boost yang dapat menaikan tegangan searah dengan output yang bervariasi. Konverter boost diusulkan menggunakan arduino uno sebagai pengendali dengan tegangan input 12 volt. Pengaturan tegangan output konverter diimplementasikan melalui pemograman arduino menggunakan simulink Matlab. Hasil eksperimen menunjukan bahwa konverter boost yang dirancang dalam penelitian ini telah bekerja dengan baik sesuai dengan tujuan. Hal ini dapat dilihat dari tegangan output konverter boost yang telah sesuai dengan tegangan referensi yang dimasukan dalam program simulink Matlab.
\end{abstract}

Kata kunci- Konverter boost, arduino uno, simulink matlab, tegangan dc.

\section{Pendahuluan}

Energi listrik adalah salah satu sumber energi yang banyak digunakan dalam kehidupan sehari-hari. Mulai dari untuk kebutuhan rumah tangga sampai dengan kebutuhan industri. Energi listrik yang dihasilkan oleh pembangkit-pembangkit tenaga listrik harus memenuhi standar kelistrikan yang dibutuhkan beban. Standar yang perlu diperhatikan adalah standar tegangan, frekuensi dan sebagainya. Ditinjau dari standar tegangan, ada dua jenis tegangan yang umum digunakan untuk berbagai kebutuhan, yaitu tegangan searah atau direct current $(\mathrm{dc})$ dan tegangan bolak balik atau disebut juga dengan alternating current (ac) [1]. Tegangan yang disuplai ke beban harus sesuai dengan rating tegangan yang dibutuhkan oleh beban tersebut. Untuk tegangan dc, ada beberapa level tegangan yang umum digunakan, seperti 6 volt, 12 volt, 24 Volt dan sebagainya. Biasanya tegangan dc ini diperoleh dari sumber batterai, accumulator atau tegangan ac yang disearahkan menggunakan konverter daya [2].

Untuk mendapatkan tegangan dc yang bervariasi, maka dibutuhkan konverter daya yang dapat menghasilkan tegangan output sesuai dengan yang dibutuhkan. Jenis konverter daya yang digunakan tergantung kepada jenis tegangan input. Jika tegangan input berupa tegangan ac maka digunakan penyearah, sedangkan jika tegangan input adalah tegangan dc, maka digunakan konverter dcdc [3]-[5]. Berdasarkan tegangan output yang dihasilkan, konverter dc-dc dapat dikelompokan atas konverter buck untuk mendapatkan tegangan yang lebih rendah dari tegangan input, konverter boost untuk mendapatkan tegangan output yang lebih besar dari tegangan input dan konverter buck-boost yang dapat menaikan dan menurunkan tegangan sehingga tegangan output-nya dapat lebih lebih dan lebih kecil dari tegangan input [6][10]. Dalam penelitian ini dirancang konverter boost untuk mendapatkan tegangan output dc yang bervariasi dengan tegangan input dc 12 volt. Konverter boost dirancang 
untuk mendapatkan tegangan yang lebih besar dari tegangan input.

Tegangan output konverter boost ditentukan oleh duty cycle pulsa modulasi sakelar konverter. Untuk mendapatkan tegangan output yang sesuai dengan keinginan, maka duty cycle ini harus diatur. Beberapa metode telah diterapkan untuk pengaturan tegangan konverter boost ini, seperti sliding mode control [11], robust control [12] dan sebagainya. Dalam penelitian ini, pengaturan tegangan output konverter boost dirancang menggunakan metode lookup table. Implementasi dari metode kontrol ini membutuhkan devais kontrol. Beberapa devais kontrol yang telah diterapkan untuk konverter boost antara lain miktokontroller Atmega [13][14] dan arduino [15]. Devais kontrol yang digunakan untuk konverter boost dalam penelitian adalah board arduino uno. Devais ini dipilih karena lebih mudah diimplementasikan. Biasanya arduino ini diprogram menggunakan software Arduino Integrated Developtment Enviroenment (IDE). Dalam penelitian ini, arduino diprogram dengan software simulink matlab. Hal ini dilakukan karena simulink matlab lebih mudah digunakan dalam mendesain sistem kendali.

\section{Metode}

Penelitian ini mengusulkan implementasi konverter boost untuk mendapatkan tegagan dc yang bervariasi. Penelitian dilakukan secara eksperimen di laboratorium. Konverter boost dirancang dengan tegangan input 12 Volt dengan tegangan output maksimum 60 Volt. Kendali tegangan output konverter boost dirancang menggunakan metode lookup table yang diimplementasikan dengan arduino yang diprogram dengan software simulink Matlab. Rancangan konverter boost yang diusulkan dalam penelitian ini dapat dilihat pada blok diagram dalam Gambar 1 berikut.

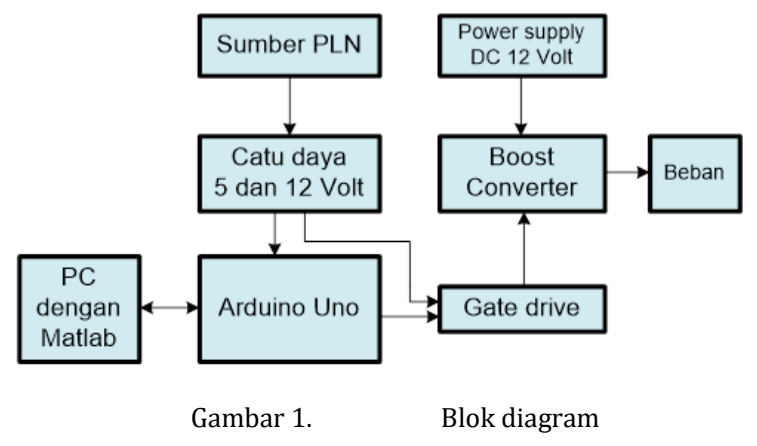

Gambar 1 menunjukan skema rancangan konverter boost yang dibuat dalam penelitian ini. Konverter boost akan bekerja menaikan tegangan dengan tegangan input 12 Volt yang melayani beban resistor. Tegangan output konverter boost ditentukan oleh waktu switching dari sakelar daya konverter boost. Waktu switching sakelar daya ini diatur dengan metode Pulse Width Modulation (PWM). Waktu switching sakelar pada PWM ini ditentukan oleh lebar pulsa modulasi, dimana lebar pulsa tersebut ditentukan oleh duty cycle. Sakelar daya yang digunakan untuk konverter boost adalah IGBT. Gambar 2 menunjukan skema konverter boost yang dirancang.

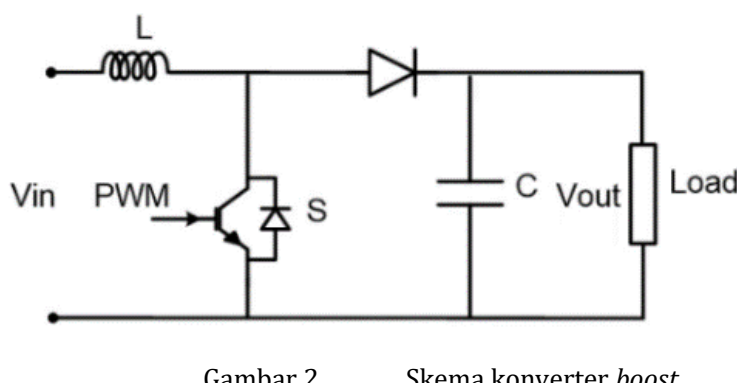

Gambar 2 menunjukan skema rangkaian konverter boost yang terdiri dari IGBT, induktor, dioda dan kapasitor. Konsep kerja konverter boost dalam menaikan tegangan adalah berdasarkan pengisian dan pengosongan induktor dan kapasitor pada rangkaian tersebut. Pengisian dan pengosongan komponen tersebut ditentukan oleh waktu switching dari sakelar daya, dimana waktu switching ini ditentukan oleh duty cycle. Hubungan tegangan output konverter boost dengan duty cycle dirumuskan dengan :

$$
V_{\text {out }}=\frac{V_{\text {in }}}{1-D}
$$

Dimana $D$ adalah duty cycle, $V_{\text {in }}$ dan $V_{\text {out }}$ adalah tegangan output dan tegangan input konverter. Berdasarkan Persamaan (1) dapat dilihat bahwa tegangan output konverter boost berbanding lurus dengan nilai duty cycle. Duty cycle ini akan mengatur lebar pulsa PWM yang akan memodulasi sakelar daya konverter. 


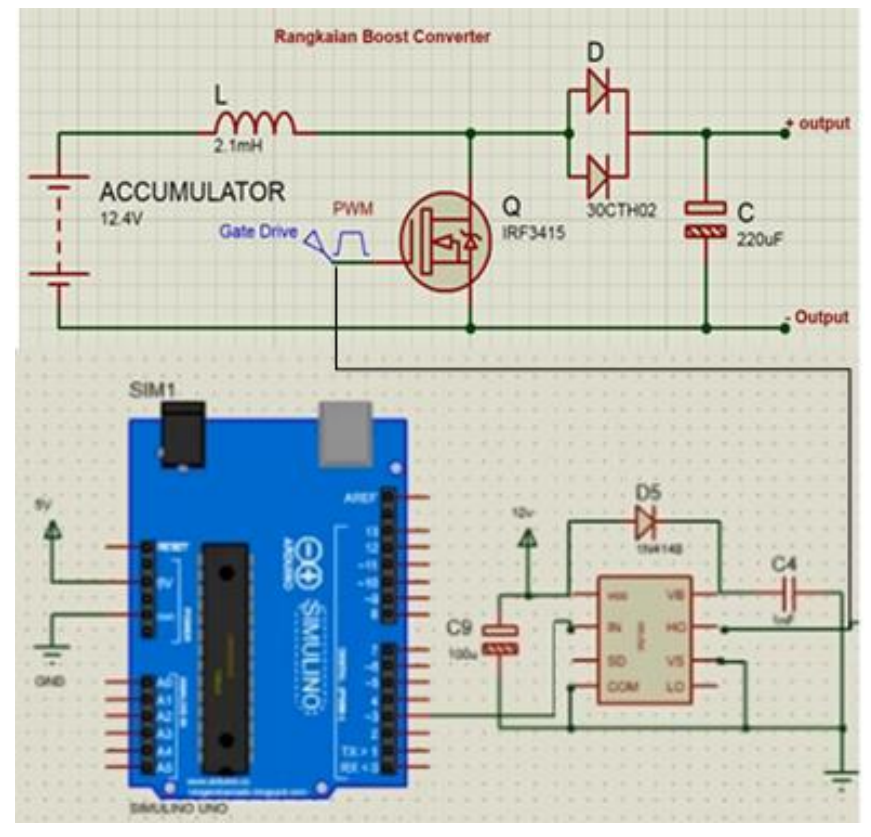

Gambar 3.

Skema rangkaian konverter dengan arduino

Dalam penelitian ini, pulsa PWM dibangkitkan melalui pin PWM arduino uno yang diprogram dengan menggunakan software simulink Matlab. Pin PWM arduino uno ini dihubungkan dengan rangkaian gate driver yang berfungsi untuk menaikan level tegangan output pin PWM arduino sesuai dengan tegangan yang dibutuhkan pin gate IGBT. Gambar 3 menunjukan skema rangkaian konverter boost yang terhubung dengan arduino uno. Gambar 4 menunjukan hardware rangkaian konverter boost yang dibuat dalam penelitian ini.

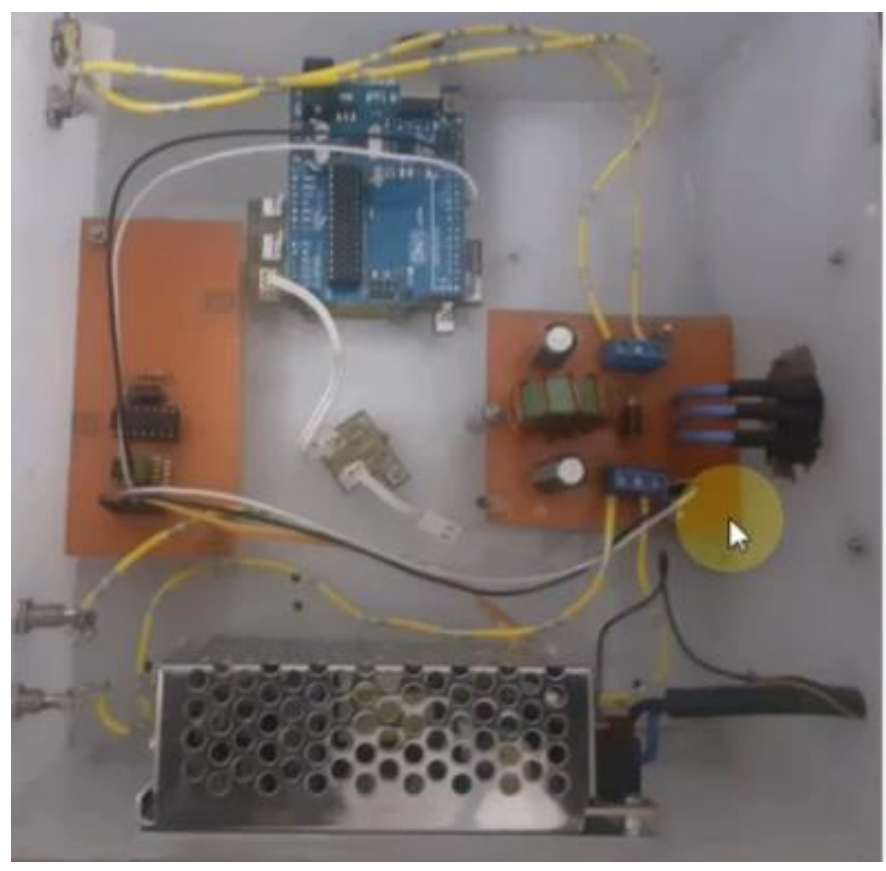

Gambar 4.

Hardware konverter boost
Pemograman arduino uno untuk mendapatkan pulsa PWM konverter boost yang sesuai dengan tegangan output yang diinginkan, maka dilakukan proses pemograman arduino dengan simulink Matlab seperti yang diuraikan dalam diagram alir pada Gambar 5. Pemogram arduino dengan simulink Matlab dimulai dengan inisialisasi port arduino pada simulink. Selanjutnya dilakukan pembuatan blok-blok program, seperti blok konstanta untuk memasukan nilai tegangan output referensi yang diinginkan, blok lookup table untuk mengkonversikan nilai tegangan referensi menjadi nilai duty cycle, blok saturation untuk membatasi nilai duty cycle yang diizinkan, blok output PWM untuk mengkonversikan nilai duty cycle menjadi pulsa PWM dan blok scope untuk menampilkan grafik tegangan referensi dan duty cycle. Blok output PWM berisikan nomor pin PWM arduino yang digunakan serta frekuensi switching dari PWM. Frekuensi switching yang digunakan untuk memodulasi sakelar daya konverter dirancang sebesar $3 \mathrm{kHz}$, sedangkan pin PWM yang digunakan adalah pin 9. Pin 9 ini kemudian dihubungkan dengan rangkaian gate drive, seperti yang ditunjukan oleh Gambar 3.

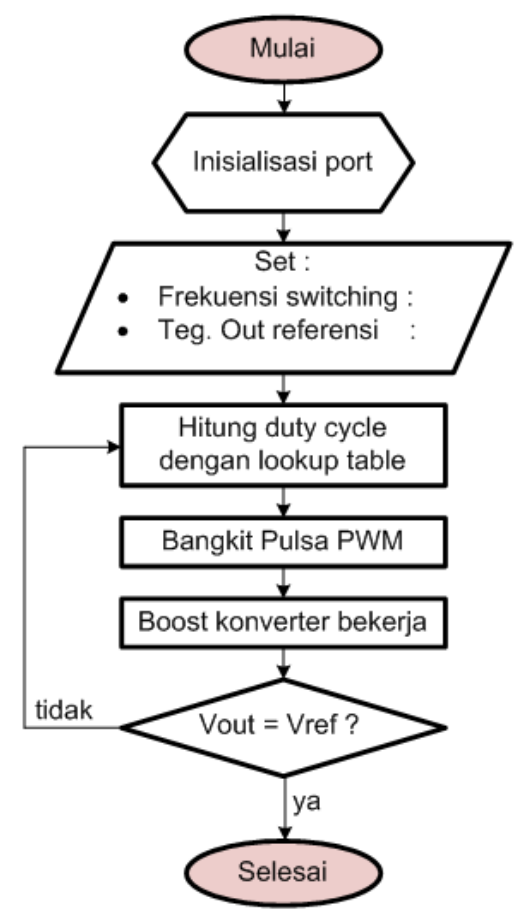

Gambar 5. Diagram alir pemograman arduino

\section{HaSil DAN PEMBahasan}

Setelah selesai membuat program arduino menggunakan simulink, selanjutnya dilakukan pengujian alat. Dalam pengujian ini, konverter dihubungkan dengan beban resistor. Untuk melihat grafik tegangan input dan tegangan output digunakan osiloskop digital, sedangkan untuk melihat grafik duty cycle dan tegangan output referensi digunakan blok scope yang ada dalam simulink 
Matlab. Gambar 6 menunjukan foto pengujian alat yang dilakukan.

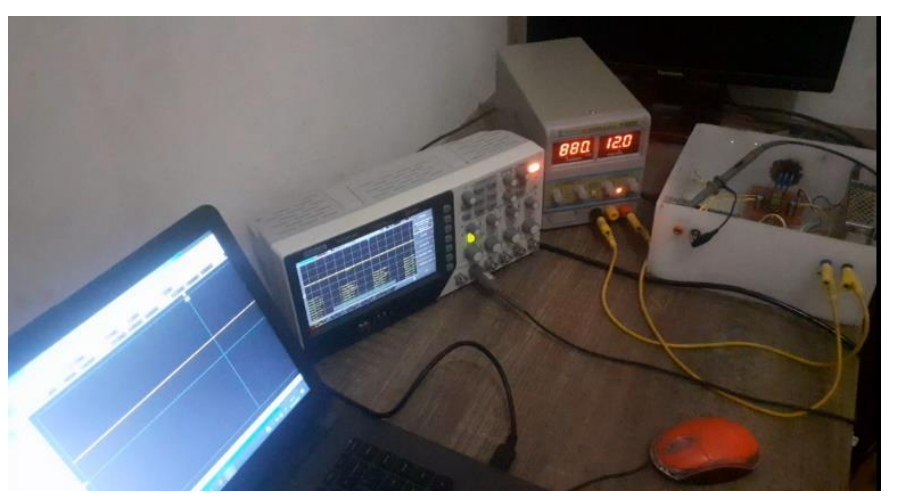

Gambar 6.

Pengujian konverter

Konverter boost yang dibuat dalam penelitian ini diuji dengan tegangan input 12 Volt yang diambil dari power supply digital, seperti yang ditunjukan dalam Gambar 6 di atas. Gambar 7 menunjukan grafik tegangan input konverter boost yang diplot menggunakan osiloskop digital dengan skala $5 \mathrm{~V} /$ div.

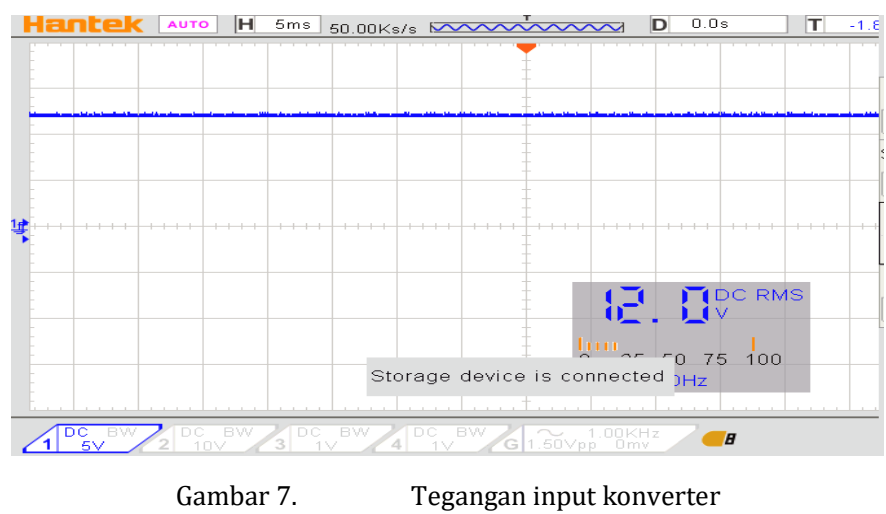

Konverter boost yang dibuat dalam penelitian ini diuji dengan tegangan output referensi sesuai dengan tegangan yang umum digunakan, yaitu 18 Volt, 24 Volt, 36 Volt, 48 Volt dan 60 Volt. Tegangan output referensi ini dimasukan dalam blok konstanta yang ada dalam program pada simulink Matlab. Gambar 8 menunjukan bentuk program konverter boost yang dibuat dalam simulink Matlab dengan tegangan output referensi 60 Volt.

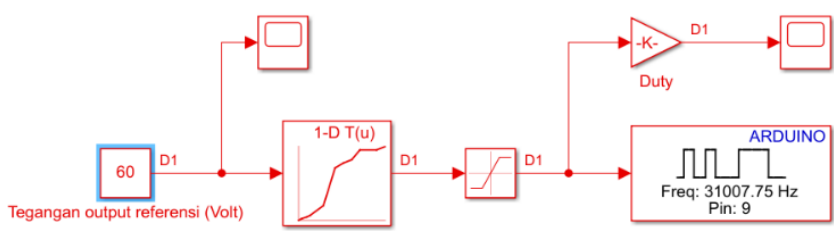

Gambar 8.
Gambar 9 menunjukan grafik tegangan output referensi dengan nilai 60 Volt dan grafik duty cycle yang dihasilkan oleh blok lookup table.
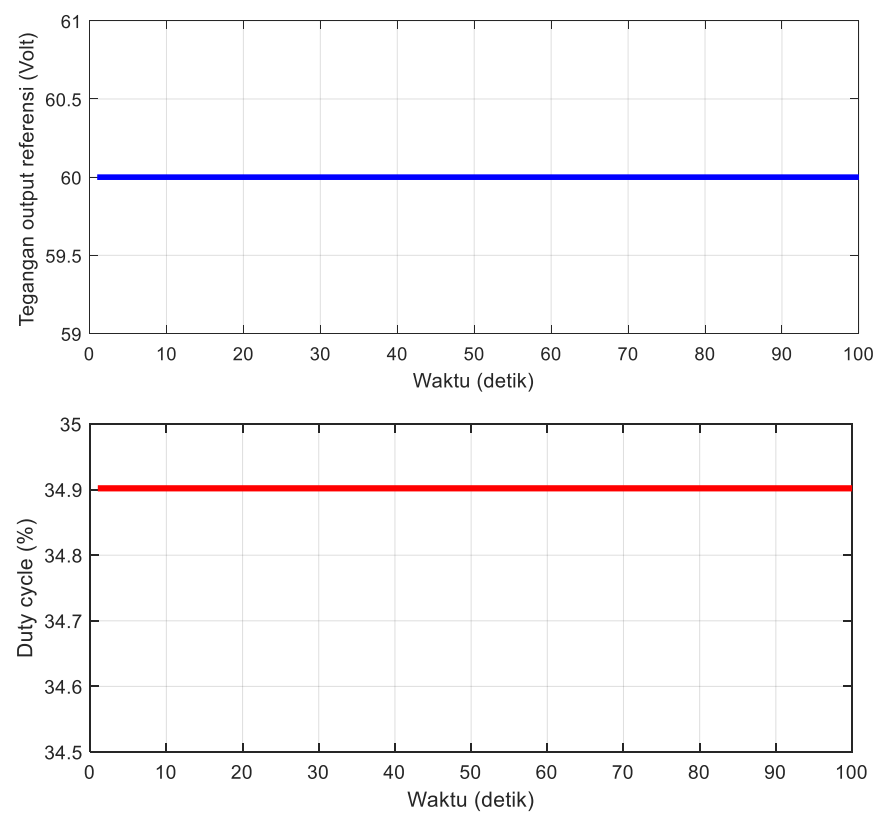

Gambar 9. Grafik tegangan output referensi dan duty cycle

Gambar 9 menunjukan bahwa duty cycle yang dihasilkan oleh blok lookup table adalah sebesar 34,9\%. Nilai ini kemudian dimasukan dalam blok output PWM untuk mendapatkan pulsa PWM yang akan memodulasi sakelar daya konverter. Gambar 10 menunjukan bentuk gelombang PWM yang dihasilkan oleh pin 9 arduino uno.

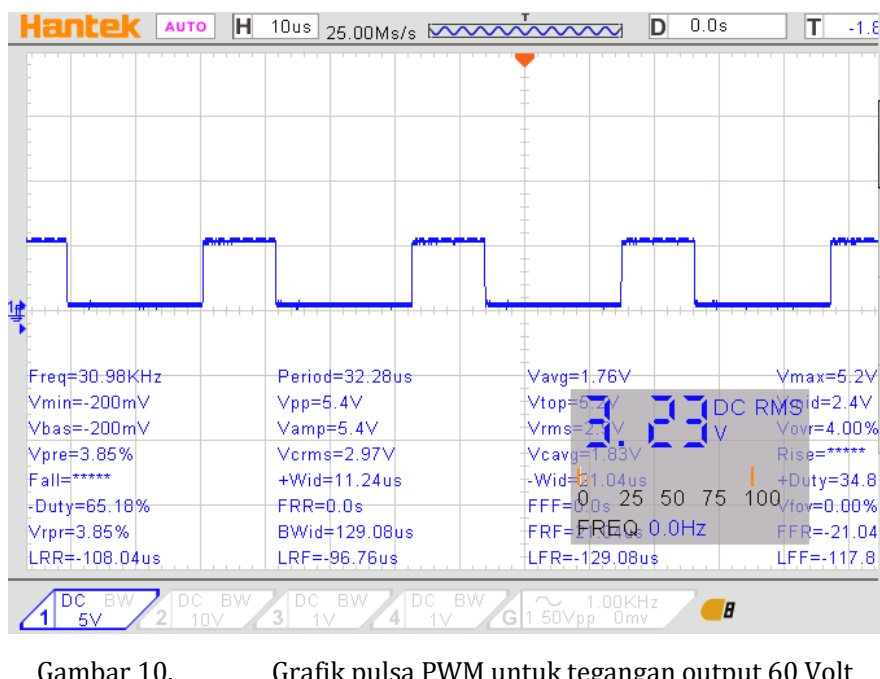

Pulsa PWM yang yang dihasilkan pin PWM arduino seperti Gambar 10 di atas telah sukses menghasilkan tegangan output sebesar 59,8 Volt. Nilai ini sudah mendekati tegangan output referensi 60 Volt. Gambar 11 menunjukan grafik tegangan output konverter boost yang 
diukur menggunakan osiloskop digital dengan skala probe 1:10 dan skala grafik 100 Volt/div.

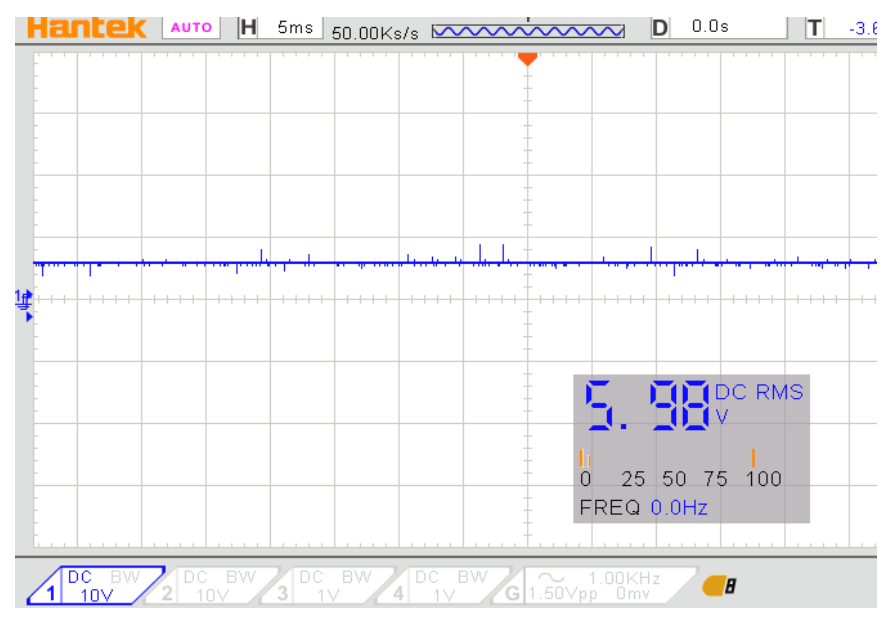

Gambar 11.

Tegangan output konverter dengan referensi 60 Volt

Hasil pengujian ini menunjukan bahwa tegangan output konverter telas sesuai dengan tegangan output referensi. Hal ini menunjukan bahwa konverter boost yang dibuat dalam penelitian ini telah bekerja dengan baik sesuai dengan perencanaan. Hasil yang serupa juga diperoleh pada pengujian lainnya dengan tegangan output referensi yang berbeda. Tabel 1 menguraikan ringkasan hasil pengujian konverter boost yang dibuat.

TABEL I. HASIL PENGUJIAN

\begin{tabular}{|c|c|c|c|}
\hline \multirow{2}{*}{ No } & \multicolumn{2}{|c|}{ Tegangan output (Volt) } & \multirow{2}{*}{ Duty cycle (\%) } \\
\cline { 2 - 3 } & Referensi & Pengukuran & \\
\hline 1 & 18 & 18 & 15,6 \\
\hline 2 & 24 & 24,2 & 16,8 \\
\hline 3 & 36 & 36,1 & 29,4 \\
\hline 4 & 48 & 48 & 33,7 \\
\hline 5 & 60 & 59,8 & 34,9 \\
\hline
\end{tabular}

Hasil pengujian konverter boost yang diuraikan dalam Tabel 1 menunjukan bahwa konverter yang dibuat telah bekerja dengan baik, dimana tegangan output yang dihasilkan sudah mendekati sama dengan tegangan output referensi yang diinginkan. Hasil pengujian menunjukan bahwa error maksimum tegangan output hanya 0,2 Volt, yakni pada saat pengujian dengan tegangan output referensi 60 Volt dan 24 Volt. Hasil pengujian dalam Tabel 1 ini juga menunjukan bahwa duty cycle PWM berbanding lurus dengan tegangan output referensi. Hal ini sesuai dengan hubungan tegangan output konverter boost dengan duty cycle yang diuraikan dalam Persamaan (1). Semua hasil ini menunjukan bahwa konverter boost yang dibuat telah bekerja dengan baik dan dapat menghasilkan tegangan output sesuai dengan tegangan referensi.

\section{KESIMPULAN}

Penelitian ini mengusulkan implementasi konverter boost menggunakan arduino uno yang diprogram dengan simulink Matlab. Konverter dibuat dengan tegangan input 12 Volt dengan tegangan output bervariasi. Konverter diuji menggunakan beban resistor dengan tegangan output bervariasi mulai dari 18 Volt sampai 60 Volt. Hasil pengujian menunjukan bahwa konverter telah bekerja dengan baik, dimana tegangan output yang dihasilkan sudah sesuai dengan tegangan output referensi. Konverter yang dibuat ini hanya menghasilkan error maksimum tegangan output sebesar 0,2 Volt. Penelitian ini dapat dikembangkan dengan menerapkan sistem kendali yang lebih baik, sehingga dapat diimplementasikan pada beban yang bervariasi.

\section{REFERENSI}

[1] Aswardi, M. Yuhendri dan D. T. Yanto, Teknik Elektronika Daya, Indonesia : IRDH Book Publisher, 2020.

[2] E. Prianto, N. Yuniarti dan D. C. Nugroho, "Boost-converter sebagai alat pengisian baterai pada sepeda listrik secara otomatis," Jurnal Edukasi Elektro, vol. 4, no. 1, pp. 52-62, 2020

[3] M. Yuhendri, Aslimeri and M. Mukhsir, "Optimum Torque Control of Stand Alone Wind Turbine Generator System Fed Single Phase Boost Inverter," $2^{\text {nd }}$ IEEE Int. Conf. on Electrical Engineering and Informatics (ICon EEI), pp. 148-153, 2019.

[4] C. Ibrahim, T. Sukmadi and A. Nugroho, "Perancangan Pengontrolan Motor Dc Menggunakan DC - DC Konverter Class C Mode Motoring dan Regenerative Breaking untuk Simulasi Kendaraan Listrik," Transient, vol. 5, no. 3, pp. 339-344, 2016

[5] M. I. Esario and M. Yuhendri, "Kendali Kecepatan Motor DC Menggunakan DC Chopper Satu Kuadran Berbasis Kontroller PI," JTEV, vol. 06, no. 01, pp. 296-305, 2020

[6] N. Rana, M. Kumar, A. Ghosh and S. Banerjee, " A Novel Interleaved Tri-State Boost Converter With Lower Ripple and Improved Dynamic Response," IEEE Trans. on Industrial Electronics, vol. 65, no. 7 , pp. $5456-5465,2018$

[7] Peeyush and V. Chaurasia, "Design and Implementation of Boost Converter for IoT Application,” Int. Journal of Innovative Research in Science, Engineering and Technology (IJIRSET), vol. 6, no. 6, June 2017.

[8] M. Cucuzzella, R. Lazzari, S. Trip, S. Rosti, C. Sandroni and A. Ferrara, "Sliding mode voltage control of boost converters in DC microgrids," Control Engineering Practice, vol. 73, pp. 161-170, April 2018

[9] M. Forouzesh, Y. P. Siwakoti, S. A. Gorji, F. Blaabjerg, and B. Lehman, "Step-Up DC-DC Converters: A Comprehensive Review of VoltageBoosting Techniques, Topologies, and Applications," IEEE Trans. on Power Electronics, vol. 32, no. 12, pp. 9143-9178, 2017

[10] F. Alonge, M. Pucci, R. Rabbeni and G.Vitale, "Dynamic modelling of a quadratic DC/DC single-switch boost converter," pp. 130-139, Electric Power Systems Research, vol. 152, Nov 2017.

[11] S. Oucheriah and L. Guo, "PWM-Based Adaptive Sliding-Mode Control for Boost DC-DC Converters. IEEE Trans. on Industrial Electronics," vol. 60, no. 8, pp. 3291-3294, 2013.

[12] M.Veerachary and Shaw, "Analysis and Design of CD-Cell Based Fifth-order Boost Converter With Robust Stability Considerations," IEEE Trans. on Industry Applications, vol. 55, no. 6, pp. 7491 - 7504, 2019.

[13] R. Ayop and C.W. Tan, "Design of boost converter based on maximum power point resistance for photovoltaic applications," Solar Energy, vol. 160, pp. 322-335, January 2018.

[14] J. R. Hernanz, J. M. Guede, O. Barambones, E. Zulueta and U. F. Gamiz, "Novel control algorithm for MPPT with boost converters in 
photovoltaic systems," International Journal of Hydrogen Energy, vol. 42, no. 28, pp. 17831-17855, 13 July 2017.

[15] N. V. Devarkar and A. Shiralkar, "Arduino Based PWM DC-DC Boost Converter for Traction System," Int. Journal of Innovative Technology and Exploring Engineering (IIITEE), vol. 8, no. 11, pp. 3651-3653, September 2019.

\section{Biodata Penulis}

Randy Setiawan menyelesaikan Sarjana Terapan di bidang Teknik Elektro Industri Pada Jurusan Teknik Elektro FT UNP.

Muldi Yuhendri, dilahirkan di Agam pada tanggal 13 Desember 1981. Menyelesaikan program Sarjana di jurusan teknik elektro Universitas Negeri Padang pada tahun 2005 dan program S2 di ITS Surabaya pada tahun 2009 serta S3 Ilmu Teknik Elektro pada tahun 2017 di kampus yang sama. Bekerja sebagai staf pengajar di jurusan teknik elektro Universitas Negeri Padang sejak tahun 2006 sampai sekarang. 